\title{
Field Measurement of Dynamic Compressive Stress Response of Pavement-Subgrade Induced by Moving Heavy-Duty Trucks
}

\author{
Lingshi An $\mathbb{D}^{1},{ }^{1}$ Feng Zhang $\mathbb{D}^{\mathbb{D}},{ }^{2}$ Yongchang Geng $\mathbb{D},{ }^{1}$ and Bo Lin ${ }^{2}$ \\ ${ }^{1}$ School of Civil Engineering, Harbin Institute of Technology, Harbin, Heilongjiang 150090, China \\ ${ }^{2}$ School of Transportation Science and Engineering, Harbin Institute of Technology, Harbin, Heilongjiang 150090, China \\ Correspondence should be addressed to Feng Zhang; fzhang_hit@163.com
}

Received 1 December 2017; Accepted 19 March 2018; Published 23 April 2018

Academic Editor: Roberto Palma

Copyright (C) 2018 Lingshi An et al. This is an open access article distributed under the Creative Commons Attribution License, which permits unrestricted use, distribution, and reproduction in any medium, provided the original work is properly cited.

\begin{abstract}
This paper presents the dynamic compressive stress response of pavement-subgrade induced by moving heavy-duty trucks. In order to study the distribution characteristic of dynamic pressure of pavement-subgrade in more detail, truck loadings, truck speeds, and dynamic pressure distributions at different depths were monitored under twenty-five working conditions on the section of Qiqihar-Nenjiang Highway in Heilongjiang Province, China. The effects of truck loading, truck speed, and depth on dynamic compressive stress response can be concluded as follows: (1) increasing truck loading will increase the dynamic pressure amplitude of subgrade-pavement and dominant frequencies are close to the characteristic frequencies caused by heavy-duty trucks at the speed of $70 \mathrm{~km} / \mathrm{h}$; (2) as truck speed increases, the dynamic pressure amplitudes of measuring points have an increasing tendency; the dynamic pressure spectrums are also significantly influenced by truck speed: the higher the truck speed, the wider the spectrum and the higher the dominant frequencies; (3) as depth increases, the dynamic pressure amplitudes of measuring points decrease rapidly. The influence of the front axle decreases gradually until disappearing and the compressive stress superposition phenomenon caused by rear double axles can be found with increasing depth.
\end{abstract}

\section{Introduction}

The stress state of pavement-subgrade has a significant effect on evaluating the stability of pavement-subgrade. However, with the rapid economic development, heavy-duty trucks which are the main cause of subgrade diseases and pavement damage in highway transportation are quite common. A large number of field investigations show that 35\%-67\% of heavy-duty trucks are overloaded in Jiangsu Province, China [1]. Furthermore, the axial loading of heavy-duty trucks approaches $22 \mathrm{t}$ on Xuanhua-Datong Highway [2]. Therefore, it is of importance to evaluate the dynamic stress of pavement-subgrade for improving the service performance of highways.

There is already growing evidence, on the basis of ongoing researches, that field measurement is an effective method to investigate the dynamic stress response of pavementsubgrade induced by moving heavy-duty trucks [3-16]. The Engineering and Physical Sciences Research Council of the United Kingdom [17] built a full-scale experimental road for testing the mechanical and subsidence properties of roads under traffic loading. Hyodo et al. $[18,19]$ investigated the vertical pressure of subgrades induced by a $10 \mathrm{t}$ car at different speeds $(0 \mathrm{~km} / \mathrm{h}, 10 \mathrm{~km} / \mathrm{h}, 20 \mathrm{~km} / \mathrm{h}$, and $35 \mathrm{~km} / \mathrm{h})$. Mateos et al. [20] carried out a field test on six sections of a circular road in Spain. The results showed that when the speed of moving vehicles increased, the compressive stress of the subgrade decreased gradually. Timm et al. [21] built eight test sections in the NCAT for testing the dynamic stress response of subgrade-pavement induced by heavy-duty trucks. The test data of the NCAT obtained by Immanuel and Timm [22] showed that temperature had a certain influence on the compressive stress response of subgrade and pavement. The compressive stress of pavement-subgrade decreased in winter and increased in summer because the stiffness of hot mix asphalt (HMA) pavement was higher in winter and lower in summer

In China, Ling et al. [23] pointed out that the vertical stress on the top of the subgrade was between $5 \mathrm{kPa}$ and $10 \mathrm{kPa}$. Zha et al. [24] tested the vibration acceleration and 
TABLE 1: Geomechanical parameters of soil.

\begin{tabular}{lccc}
\hline Specific gravity & Cohesion force & Friction angle & Dynamic elastic modulus \\
\hline 2.61 & $94 \mathrm{kPa}$ & $37^{\circ}$ & $490 \mathrm{MPa}$ \\
\hline
\end{tabular}

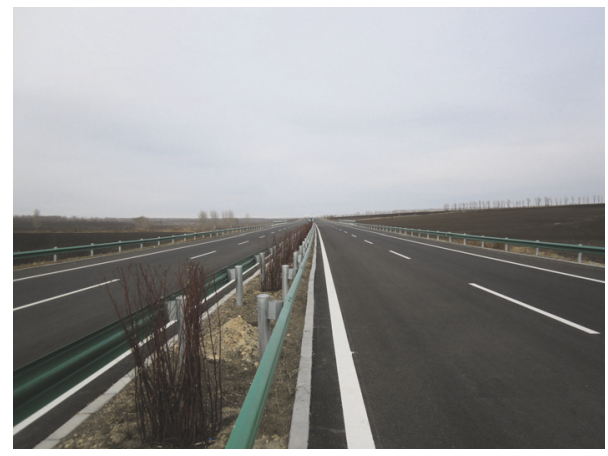

FIgURE 1: Monitoring section of Qiqihar-Nenjiang Highway in Heilongjiang Province, China.

dynamic pressure of pavement induced by Dongfeng Trucks and Jinbei buses. The results showed that the dynamic pressure amplitude of pavement was $38.6 \mathrm{kPa}$ for trucks and only $3.78 \mathrm{kPa}$ for buses. Wang et al. [25] found that the dynamic pressure of subgrade-pavement decreased with increasing vertical depth and increased with increasing truck loading. Wang et al. [26] discussed the effects of axle loading, road roughness, and truck speed on the additional stress induced by traffic loading. Zhao et al. [27] tested the dynamic stress and dynamic displacement of subgrade induced by $2 \mathrm{t}$ and $20 \mathrm{t}$ trucks. The results showed that the dynamic pressure and dynamic displacement of subgrade increased with increasing truck speed. Shi et al. [28] measured the dynamic stress of subgrade induced by trucks and suggested that the stress amplitude was from 0 to $100 \mathrm{kPa}$ on the top of the subgrade. Cui et al. [29] found that the cumulative settlement of subgrade obviously increased with increasing wheel load.

In this paper, in situ tests on the section of QiqiharNenjiang Highway in Heilongjiang Province, China, are presented. The main objective of this paper is to get a better understanding of the dynamic compressive stress response of pavement-subgrade induced by moving heavy-duty trucks. The effects of truck loading, truck speed, and depth on the dynamic compressive stress response are analyzed. In addition, this paper would be helpful to provide a series of test data that researchers can use for further investigation and for the validation of numerical prediction models.

\section{Measurement Details}

\subsection{Test Section and Materials of Subgrade}

2.1.1. Test Section. As shown in Figure 1, field measurement site is the K46+732 section of Qiqihar-Nenjiang Highway in Heilongjiang Province, China.

The Qiqihar-Nenjiang Highway is a bidirectional, fourlane highway. The asphalt concrete pavement is composed

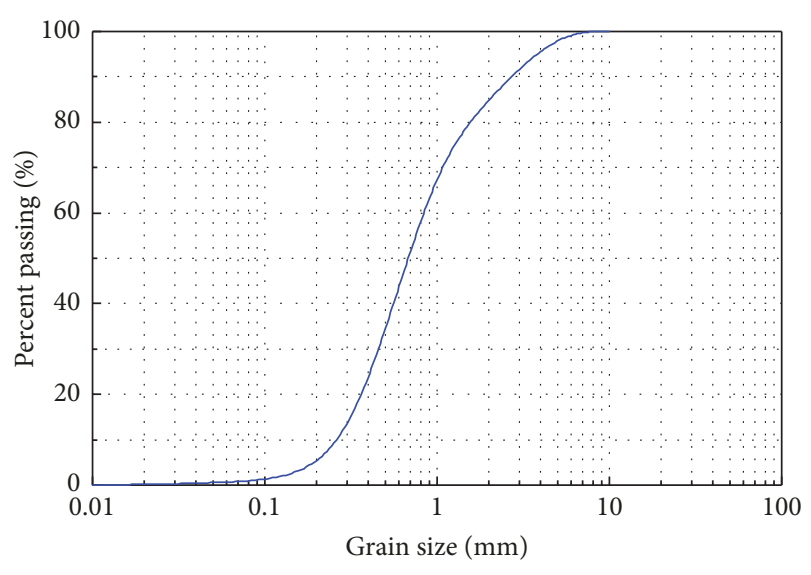

FIGURE 2: Grain size distribution of subgrade soil.

of three layers as follows: the up layer of asphalt concrete (AC16) with a thickness of $0.05 \mathrm{~m}$, the middle layer of asphalt concrete (AC20) with a thickness of $0.06 \mathrm{~m}$, and the bottom layer of large-size asphalt macadam (ATB25) with a thickness of $0.08 \mathrm{~m}$. The thickness of the base course of cementstabilized macadam is $0.2 \mathrm{~m}$ and the thickness of the subbase course of cement-stabilized gravel is $0.23 \mathrm{~m}$.

2.1.2. Materials of Subgrade. According to the Test Methods of Soils for Highway Engineering (JTG E40-2007) issued by the Ministry of Transport, China, the grain size distribution of subgrade soil is shown in Figure 2.

The uniformity coefficient $C_{u}$ and curve coefficient $C_{c}$ are calculated as 3.2 and 1.013, respectively. The maximum dry-unit weight is $2010 \mathrm{~kg} / \mathrm{m}^{3}$ at the optimum water content of $8.63 \%$. A series of unconsolidated-undrained triaxial compression tests and dynamic triaxial tests on the remolded subgrade soil with optimum water content and maximum dry-unit weight are performed to obtain the geomechanical parameters which are shown in Table 1.

2.2. Test Points and Sensor Installation. To investigate the vertical dynamic stress of pavement-subgrade induced by moving heavy-duty trucks, ten test points were chosen according to the Specifications for Design of Highway Subgrade (JTGD30-2004) issued by the Ministry of Transport, China. These test points were located on the top of the base course, the top of the roadbed, the top of the upembankment, the top of the subembankment, and the bottom of the subembankment. Figure 3 shows the layout of the dynamic soil pressure cells. During the construction process of subgrade and pavement, ten dynamic soil pressure cells with a diameter of $180 \mathrm{~mm}$ and a height of $22 \mathrm{~mm}$ were buried at different depths $(0.19 \mathrm{~m}, 0.62 \mathrm{~m}, 1.42 \mathrm{~m}, 2.12 \mathrm{~m}$, and $3.12 \mathrm{~m})$. The horizontal distance of dynamic soil pressure cells $(1.83 \mathrm{~m})$ was close to the rear wheel distance of normal heavy-duty trucks in China. 


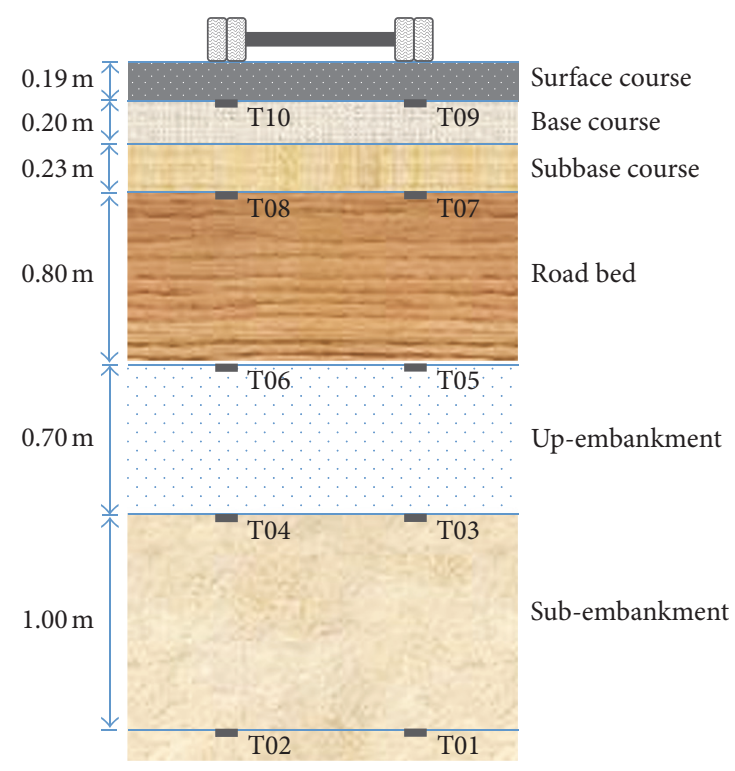

FIGURE 3: Location and placement of soil pressure cells (units: m).

The dynamic soil pressure cells (BY-1) used in the field tests were produced by Dandong Qiulong Sensor Manufacturing Co., Ltd. The measurement range of the sensor was from 0 to $200 \mathrm{kPa}$ and the sensitivity was $1 \mathrm{mv} / \mathrm{v}$ dimension. The operating temperature of the sensor was from $-30^{\circ} \mathrm{C}$ to $60^{\circ} \mathrm{C}$.

To avoid the damage of data line during the construction process of subgrade and pavement, cable lines were firstly protected by a soft plastic pipe and the joint between cells and the plastic pipe was twined with waterproof adhesive tape. Then, the sensors were put in a predug groove and covered by soil or asphalt. Figure 4 shows the installation process of sensors.

2.3. Heavy-Duty Truck. A three-axle heavy-duty truck manufactured by FAW Group Corporation is chosen, as shown in Figure 5(a). The dimensions of the test truck are shown in Figures 5(b)-5(d). The length of the whole truck is $8.9 \mathrm{~m}$ and the width is $2.5 \mathrm{~m}$. The front axle distance is $3.5 \mathrm{~m}$ and the rear axle distance is $1.35 \mathrm{~m}$. The front wheel distance is $2.02 \mathrm{~m}$ and the rear wheel distance is $1.83 \mathrm{~m}$.

When the truck runs on the road, the periodic loading is applied on the pavement and subgrade. The periodic frequency is related to the dimensions and speed of the heavyduty truck. The characteristic frequency can be calculated by

$$
f_{i}=\frac{v}{L_{i}} \quad i=1,2,3
$$

where $f_{i}$ is the characteristic frequency of pavementsubgrade generated by moving heavy-duty trucks $(\mathrm{Hz}), v$ is the heavy-duty truck's speed $(\mathrm{m} / \mathrm{s})$, and $L_{i}$ is the characteristic distance of the heavy-duty truck. For three-axle heavy-duty trucks, there are three kinds of characteristic distances as follows: the distance of the front axle to the center of the rear double axles $\left(L_{1}=3.5+1.35 / 2=4.175 \mathrm{~m}\right)$, the distance between the left and the right rear wheel groups $\left(L_{2}=1.83 \mathrm{~m}\right)$, and the distance between the rear double axles $\left(L_{3}=1.35 \mathrm{~m}\right)$.
TABLE 2: Field tests under twenty-five working conditions.

\begin{tabular}{|c|c|c|}
\hline $\begin{array}{l}\text { Working } \\
\text { condition }\end{array}$ & $\begin{array}{c}\text { Truck } \\
\text { loading } \\
(\mathrm{kN})\end{array}$ & $\begin{array}{c}\text { Truck } \\
\text { speed } \\
(\mathrm{km} / \mathrm{h}) \\
\end{array}$ \\
\hline 1 & \multirow{9}{*}{140} & 5 \\
\hline 2 & & 10 \\
\hline 3 & & 20 \\
\hline 4 & & 30 \\
\hline 5 & & 40 \\
\hline 6 & & 50 \\
\hline 7 & & 60 \\
\hline 8 & & 70 \\
\hline 9 & & 80 \\
\hline 10 & \multirow{9}{*}{328.9} & 5 \\
\hline 11 & & 10 \\
\hline 12 & & 20 \\
\hline 13 & & 30 \\
\hline 14 & & 40 \\
\hline 15 & & 50 \\
\hline 16 & & 60 \\
\hline 17 & & 70 \\
\hline 18 & & 80 \\
\hline 19 & \multirow{7}{*}{533.8} & 10 \\
\hline 20 & & 20 \\
\hline 21 & & 30 \\
\hline 22 & & 40 \\
\hline 23 & & 50 \\
\hline 24 & & 60 \\
\hline 25 & & 70 \\
\hline
\end{tabular}

2.4. Test Procedure and Data Acquirement. Before field test, the front axle load and rear two-axle loads were measured by wagon balance. There were three whole truck loadings as follows: $533.8 \mathrm{kN}(76.6 \mathrm{kN}$ of front axle and $457.2 \mathrm{kN}$ of rear axles), $328.9 \mathrm{kN}$ ( $92.4 \mathrm{kN}$ of front axle and $236.5 \mathrm{kN}$ of rear axles), and $140 \mathrm{kN}$ ( $51.1 \mathrm{kN}$ of front axle and $88.9 \mathrm{kN}$ of rear axles). In addition, the heavy-duty truck speeds were $80 \mathrm{~km} / \mathrm{h}, 70 \mathrm{~km} / \mathrm{h}, 60 \mathrm{~km} / \mathrm{h}, 50 \mathrm{~km} / \mathrm{h}, 40 \mathrm{~km} / \mathrm{h}, 30 \mathrm{~km} / \mathrm{h}$, $20 \mathrm{~km} / \mathrm{h}, 10 \mathrm{~km} / \mathrm{h}$, and $5 \mathrm{~km} / \mathrm{h}$.

A DH3840 signal amplifier instrument and DH5932 signal acquisition system (manufactured by Donghua Testing Technology Co., Ltd.) were adopted to measure the dynamic stress. The sampling frequency was set to $200 \mathrm{~Hz}$. The response of the dynamic stress of pavement-subgrade was recorded by the monitoring system.

Field tests under twenty-five working conditions were performed to investigate the distribution characteristic of dynamic pressure of pavement-subgrade induced by moving heavy-duty trucks. The working conditions are listed in Table 2. The general situation of field tests is shown in Figure 6. 


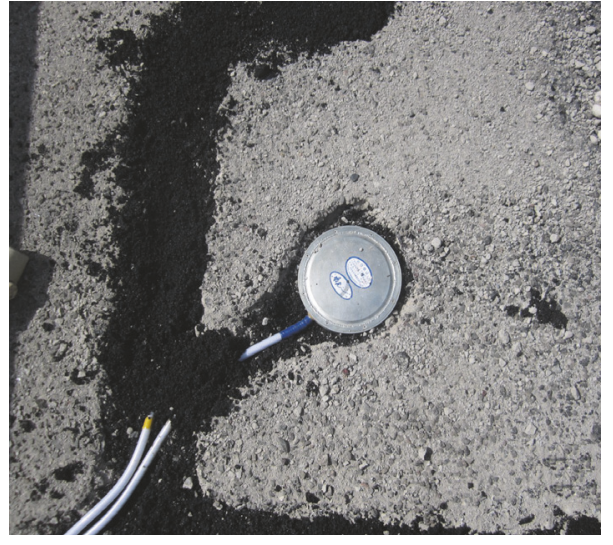

(a)

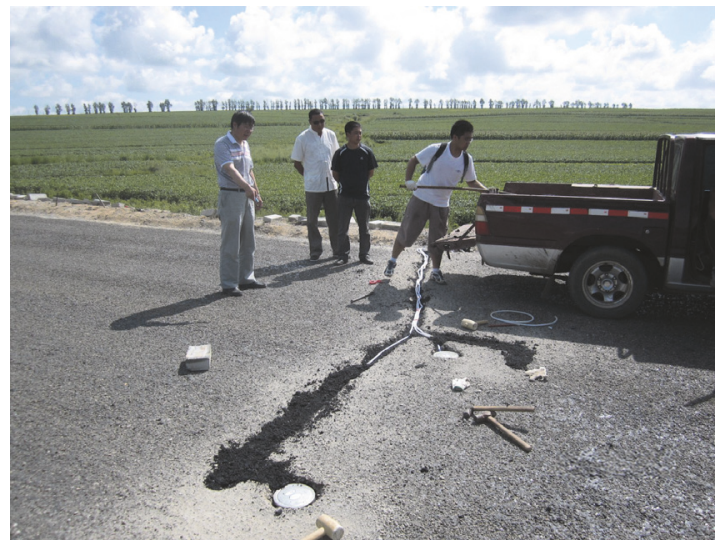

(b)

FIGURE 4: Installation process of the sensor.

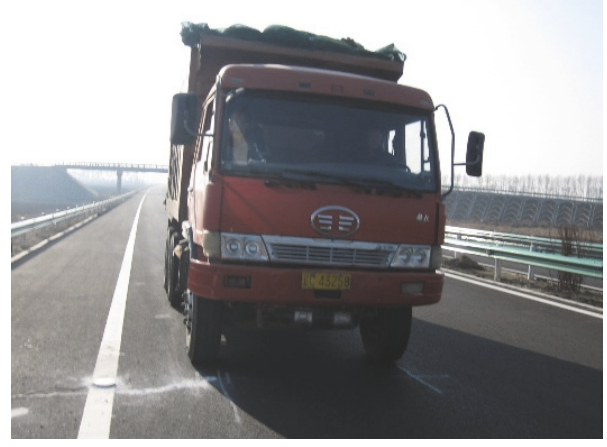

(a)

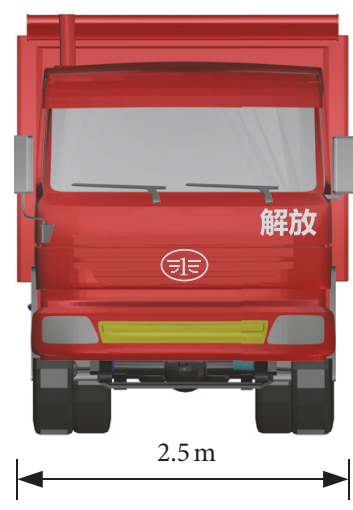

(b)

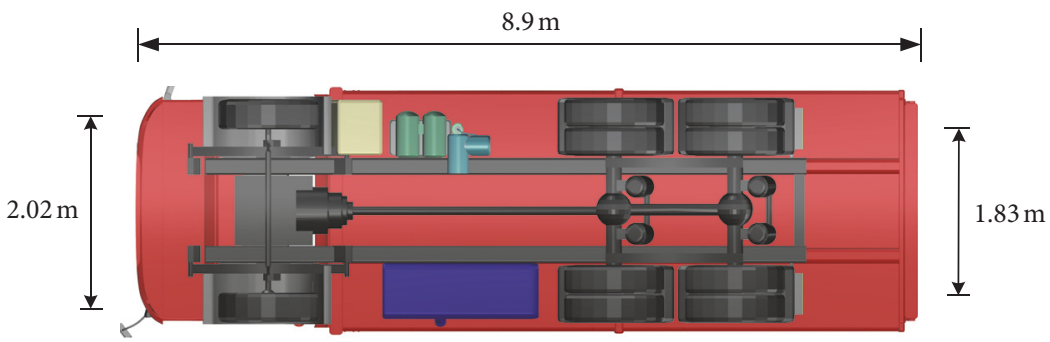

(c)

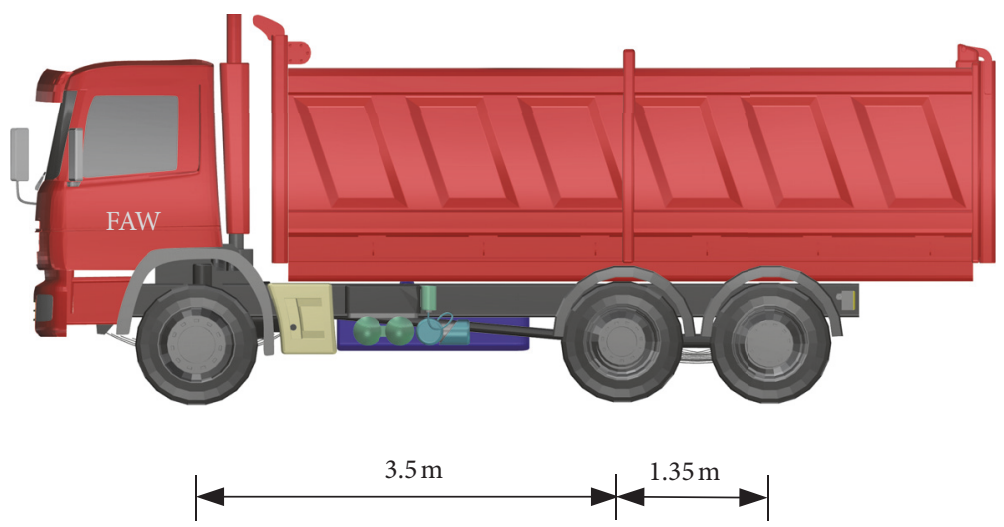

(d)

FIgURE 5: Dimensions of the test truck. 


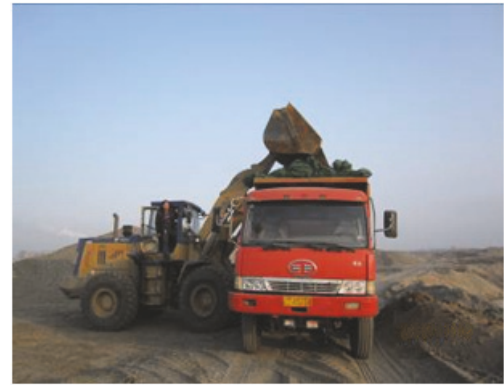

(a)

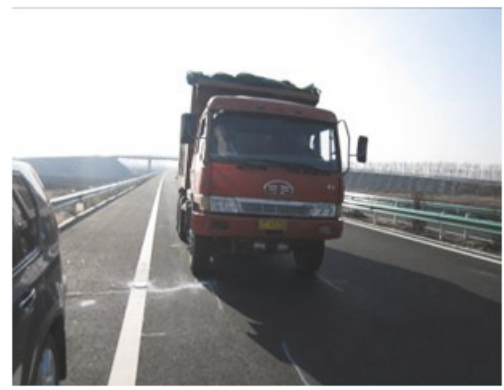

(d)

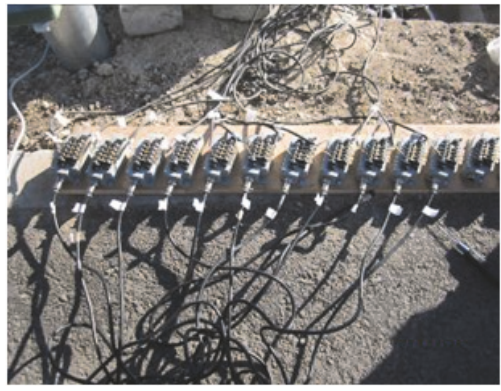

(b)

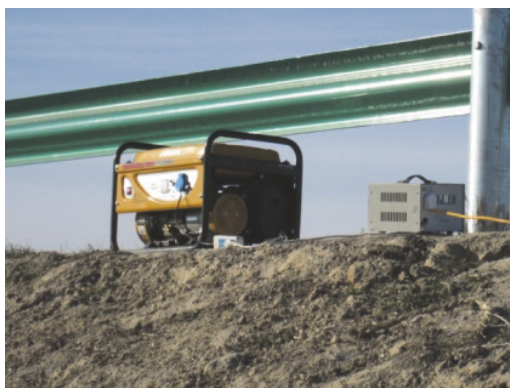

(e)

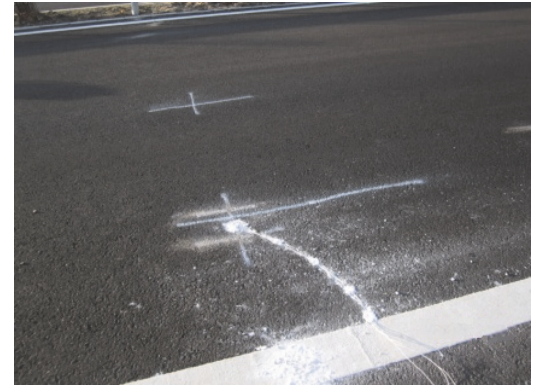

(c)

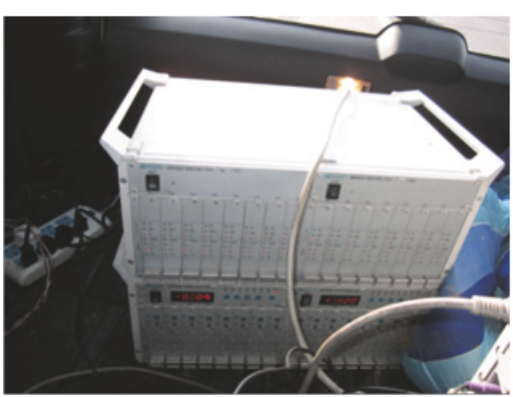

(f)

FIGURE 6: General situation of field monitoring.

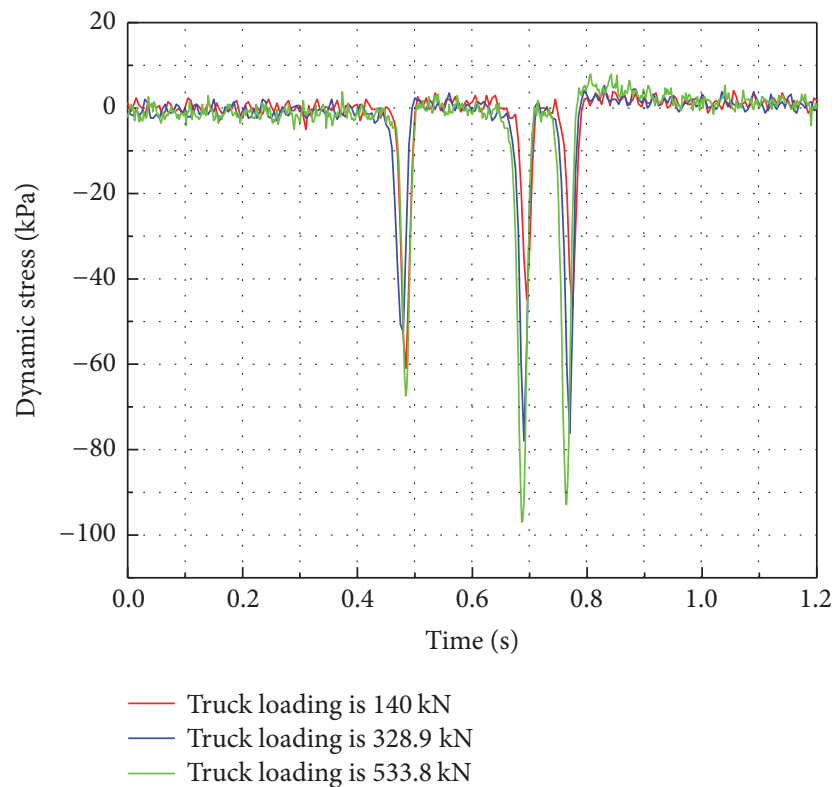

FIgURE 7: Time history curves of dynamic pressure on the top of the base course under different truck loadings.

\section{Results and Analysis}

3.1. Effect of Truck Loading. Figure 7 shows the time history curves of dynamic pressure on the top of the base course at the truck speed of $70 \mathrm{~km} / \mathrm{h}$ under different loadings $(140 \mathrm{kN}$, $328.9 \mathrm{kN}$, and $533.8 \mathrm{kN}$ ). It can be seen that there are three compressive stress peaks which are induced by the three axles of heavy-duty trucks and the compressive stress peaks caused by the rear double axles are almost equal. When the whole truck loading is $140 \mathrm{kN}$, the dynamic compressive

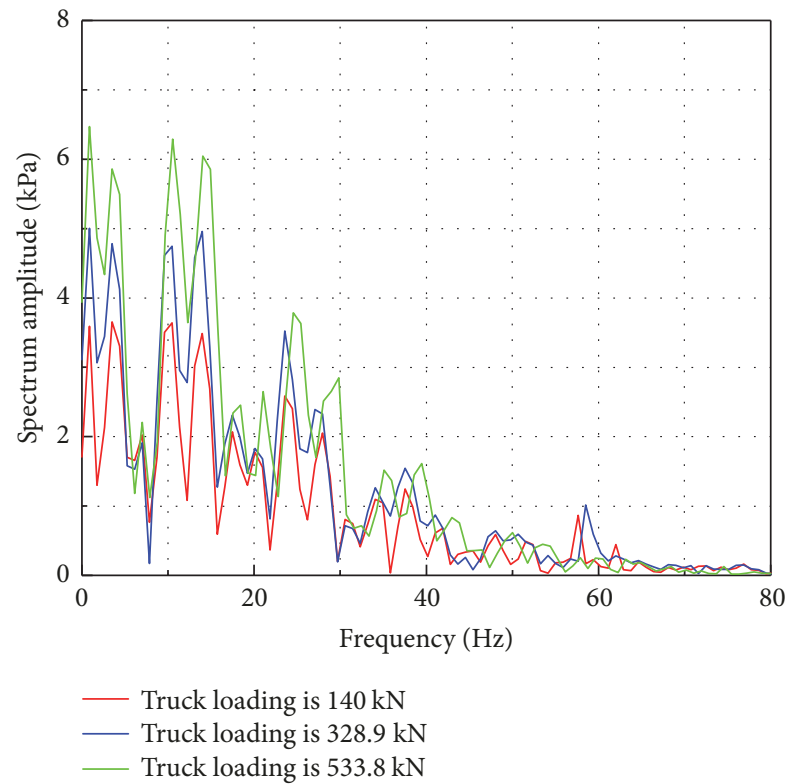

FIGURE 8: Spectrum curves of dynamic pressure on the top of the base course under different truck loadings.

stress amplitude caused by the front axle is greater than that caused by the rear double axles. However, when the whole truck loading is $328.9 \mathrm{kN}$ or $533.8 \mathrm{kN}$, the compressive stress amplitude caused by the front axle is weaker than that caused by the rear double axles. One reason which can explain this phenomenon is that the gravity center of the test truck moves backward as the whole truck loading increases.

As shown in Figure 8, time history curves are converted to spectrum curves by the fast Fourier transformation to 
TABLE 3: Maximum dynamic stress at different truck speeds.

\begin{tabular}{lcccccccccc}
\hline \multirow{2}{*}{ Truck loading $(\mathrm{kN})$} & Depth $(\mathrm{m})$ & \multicolumn{9}{c}{ Truck speed $(\mathrm{km} / \mathrm{h})$} \\
& & 80 & 70 & 60 & 50 & 40 & 30 & 20 & 10 \\
\hline & 0.19 & -74.9 & -79.7 & -62.2 & -81.9 & -75.7 & -66.2 & -54 & -73.9 & -72.9 \\
328.9 & 0.62 & -25.3 & -27.5 & -26.2 & -24.8 & -24.3 & -24.1 & -20.9 & -20.5 & -13.2 \\
& 1.42 & -24.2 & -20.8 & -19.7 & -19.4 & -18.8 & -19.7 & -18 & -18.4 & -9.4 \\
& 2.12 & -15 & -12 & -15.9 & -16.8 & -14.7 & -14.1 & -13.7 & -9 & -6 \\
& 3.12 & -9.6 & -7.9 & -6.3 & -8.3 & -9.6 & -7.6 & -7.6 & -6.3 & -3.6 \\
\hline
\end{tabular}

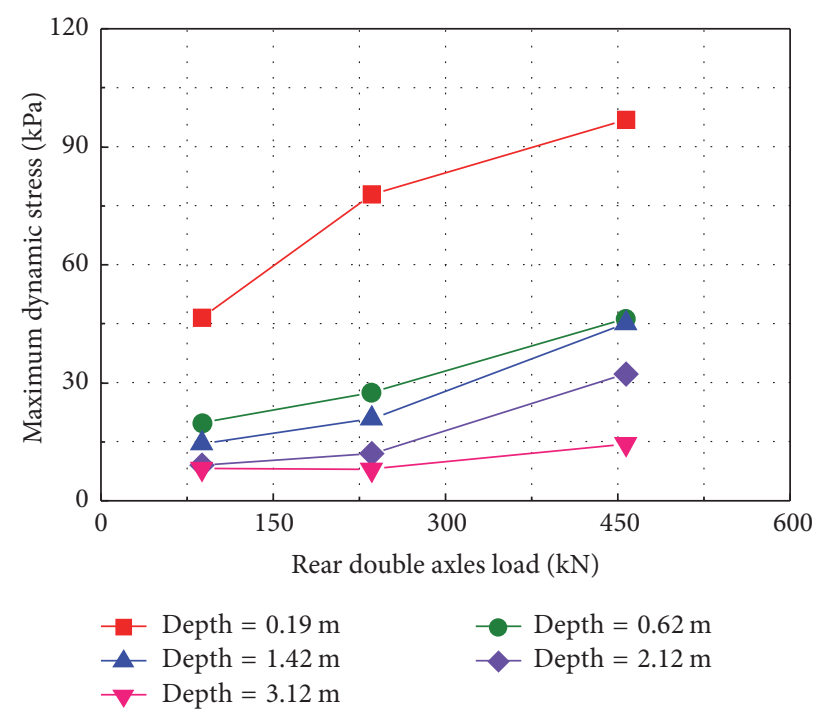

FIGURE 9: Relationship between rear double axles load and maximum dynamic stress.

analyze the frequency-domain characteristics. The significant frequency components are between 0 and $50 \mathrm{~Hz}$. Figure 8 also indicates that the first dominant frequency is $0.83 \mathrm{~Hz}$. The second dominant frequency is $3.9 \mathrm{~Hz}$ and it is close to the characteristic frequency $\left(f_{1}=4.65 \mathrm{~Hz}\right)$ caused by $L_{1}$ of heavy-duty trucks. The third dominant frequency is $10.16 \mathrm{~Hz}$ and it is close to the characteristic frequency $\left(f_{2}=10.63 \mathrm{~Hz}\right)$ caused by $L_{2}$ of heavy-duty trucks. The fourth dominant frequency is $14.06 \mathrm{~Hz}$ and it is close to the characteristic frequency $\left(f_{3}=14.4 \mathrm{~Hz}\right)$ caused by $L_{3}$ of heavy-duty trucks. The reason why the three dominant frequencies are smaller than the three characteristic frequencies caused by heavyduty trucks is that some of the vibration components are absorbed by asphalt concrete pavement. Furthermore, it can be observed that dominant frequencies are identical while the spectrum amplitude is different when the whole truck loading increases from $140 \mathrm{kN}$ to $533.8 \mathrm{kN}$.

Figure 9 shows the relationship between the maximum dynamic stress and the rear double axles load at a truck speed of $70 \mathrm{~km} / \mathrm{h}$ at different depths. It can be seen that the rear double axles load plays a significant role in the dynamic stress of pavement-subgrade and the maximum dynamic stress increases with the increase of truck loading for a certain depth. In addition, when the rear double axles load increases from $88 \mathrm{kN}$ to $457 \mathrm{kN}$, the maximum dynamic stress amplitude increases from $46.6 \mathrm{kPa}$ to $96.9 \mathrm{kPa}$ which means a 107 percent growth can be found.
3.2. Effect of Truck Speed. Figure 10 shows the time history curves of dynamic stress on the top of the base course at the speeds of $5 \mathrm{~km} / \mathrm{h}, 10 \mathrm{~km} / \mathrm{h}, 20 \mathrm{~km} / \mathrm{h}, 30 \mathrm{~km} / \mathrm{h}, 40 \mathrm{~km} / \mathrm{h}$, $50 \mathrm{~km} / \mathrm{h}, 60 \mathrm{~km} / \mathrm{h}, 70 \mathrm{~km} / \mathrm{h}$, and $80 \mathrm{~km} / \mathrm{h}$ when the truck loading is $328.9 \mathrm{kN}$. The three obvious dynamic stress peaks are induced by the three axles of heavy-duty trucks. In addition, the maximum dynamic stress is caused by the front axle for the truck speeds of $5 \mathrm{~km} / \mathrm{h}, 10 \mathrm{~km} / \mathrm{h}, 20 \mathrm{~km} / \mathrm{h}$, $50 \mathrm{~km} / \mathrm{h}$, and $80 \mathrm{~km} / \mathrm{h}$. It seems that the pitching motion of moving heavy-duty trucks can account for this phenomenon. During the pitching down process, the gravity center of the test truck moves forward and the front wheels have bigger dynamic stress.

Table 3 shows the maximum dynamic stresses at different truck speeds. It could be seen that truck speed has a certain effect on dynamic pressure. The dynamic pressure amplitudes of measuring points in up-embankment and subembankment increase with the increase of truck speed. Park et al. [30], Xia et al. [31], and Feng et al. [32] also found that dynamic pressure exhibited an increasing tendency with increasing truck speed. The possible reason is that high frequency vibrations are absorbed by soil and the vibrations with low frequency become the dominant vibrations gradually as the truck loading transfers from top to bottom.

Figure 11 shows the spectrum curves of dynamic stress on the top of the base course at different speeds $(5 \mathrm{~km} / \mathrm{h}$, $10 \mathrm{~km} / \mathrm{h}, 30 \mathrm{~km} / \mathrm{h}, 50 \mathrm{~km} / \mathrm{h}$, and $70 \mathrm{~km} / \mathrm{h}$ ) when truck loading 


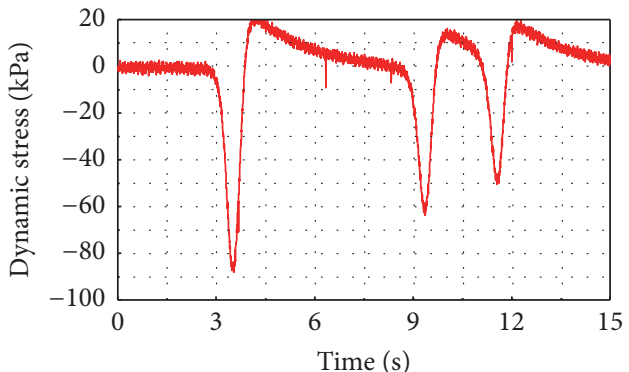

(a)

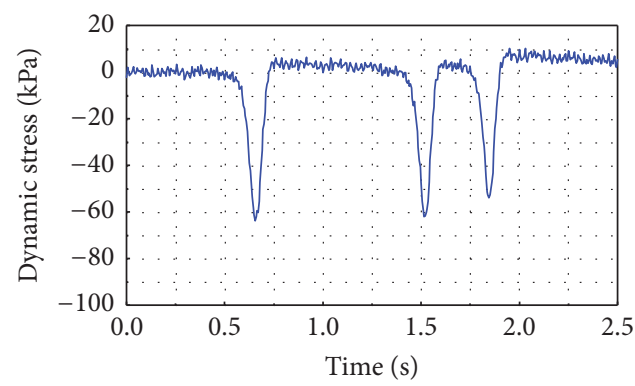

(c)

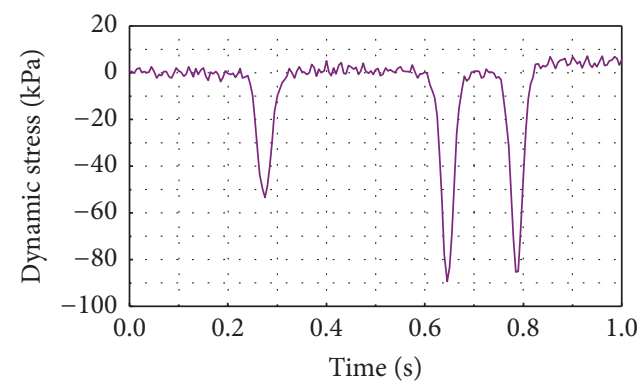

(e)

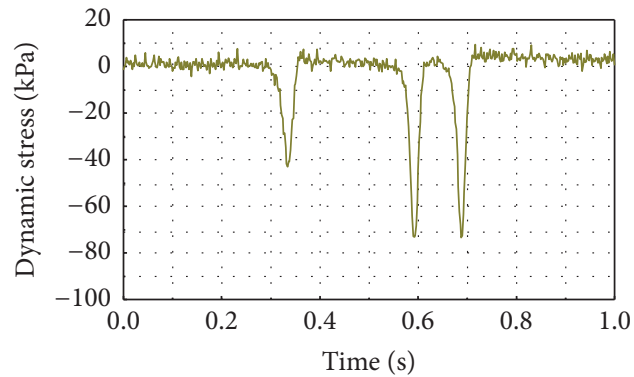

(g)

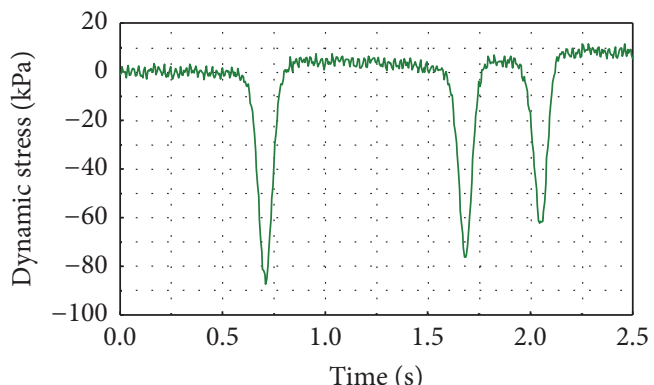

(b)

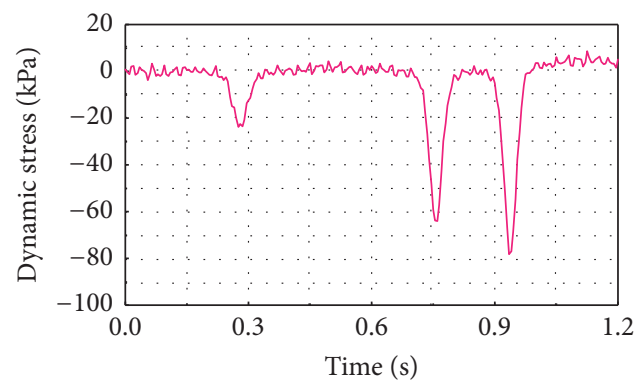

(d)

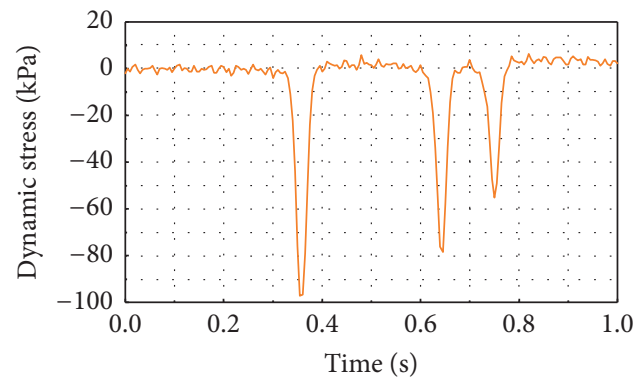

(f)

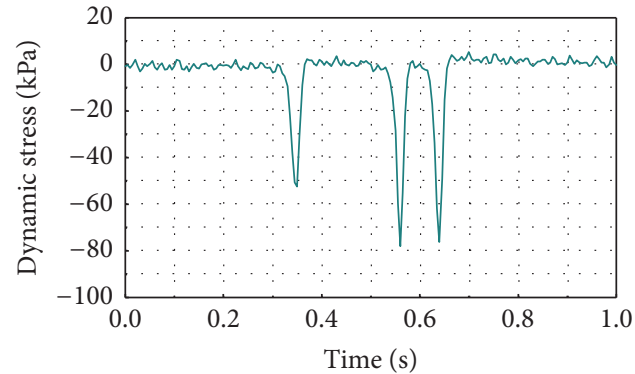

(h)

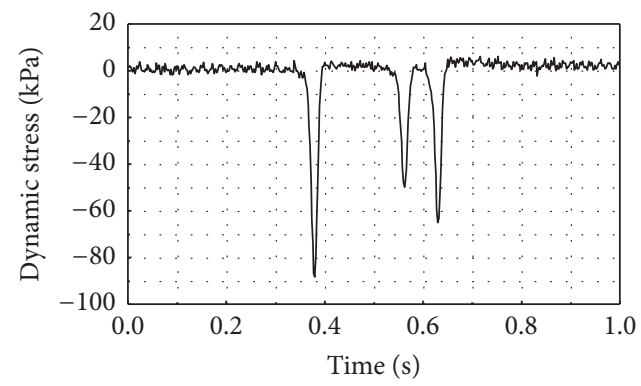

(i)

FIGURE 10: Time history of dynamic pressure on the top of the base course at different truck speeds: (a) $5 \mathrm{~km} / \mathrm{h},(\mathrm{b}) 10 \mathrm{~km} / \mathrm{h},(\mathrm{c}) 20 \mathrm{~km} / \mathrm{h},(\mathrm{d})$ $30 \mathrm{~km} / \mathrm{h}$, (e) $40 \mathrm{~km} / \mathrm{h}$, (f) $50 \mathrm{~km} / \mathrm{h}$, (g) $60 \mathrm{~km} / \mathrm{h}$, (h) $70 \mathrm{~km} / \mathrm{h}$, and (i) $80 \mathrm{~km} / \mathrm{h}$. 


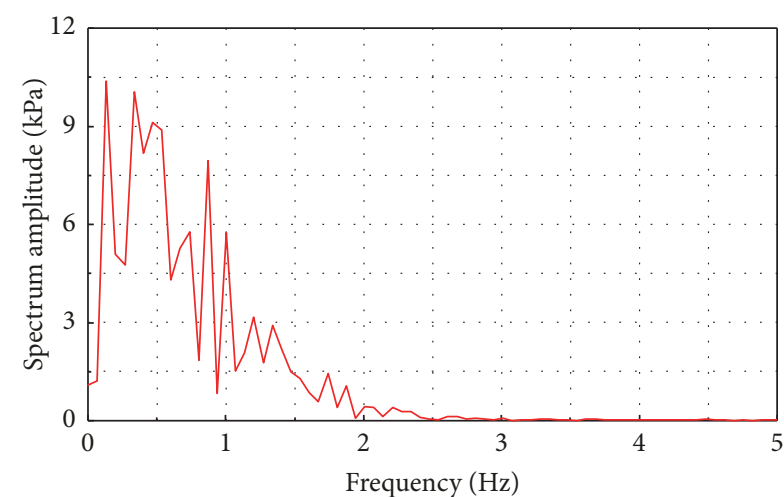

(a)

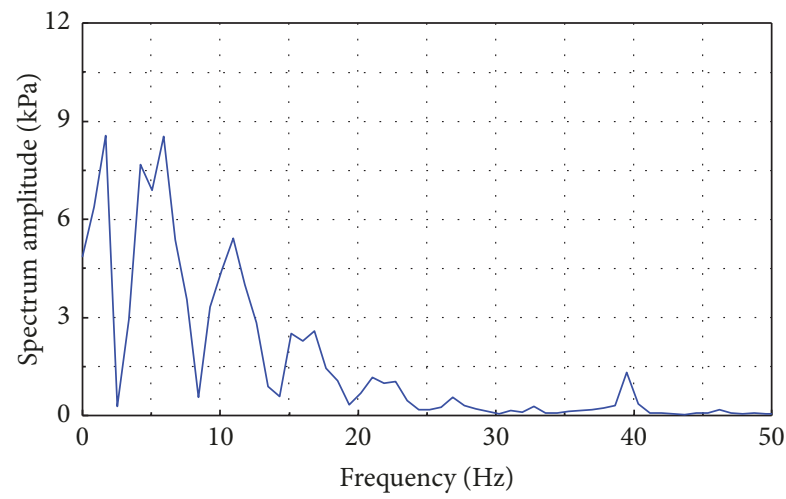

(c)

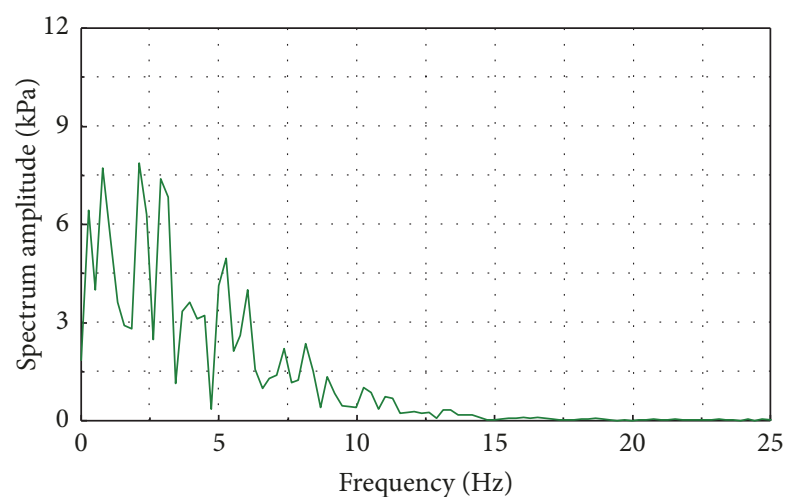

(b)

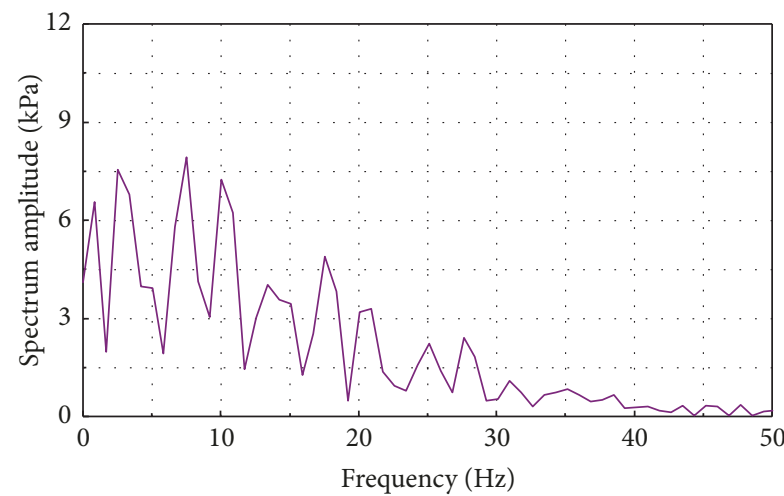

(d)

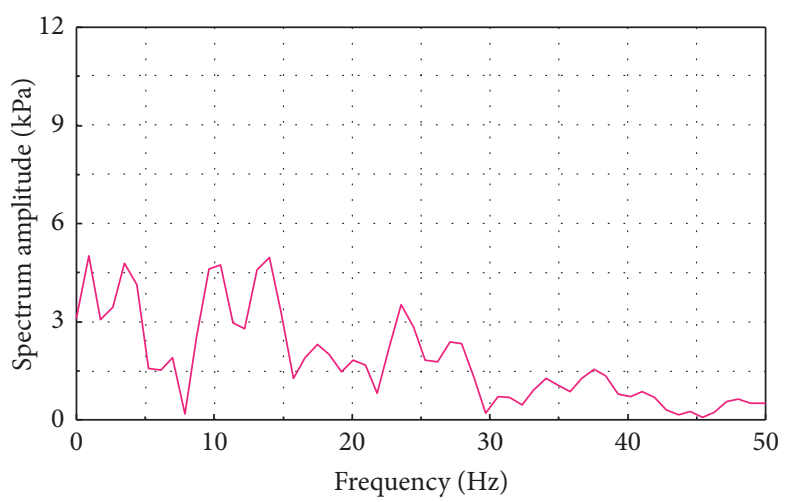

(e)

FIGURE 11: Spectrum curves of dynamic stress on the top of the base course when the truck's speed is (a) $5 \mathrm{~km} / \mathrm{h},(\mathrm{b}) 10 \mathrm{~km} / \mathrm{h}$, (c) $30 \mathrm{~km} / \mathrm{h}$, (d) $50 \mathrm{~km} / \mathrm{h}$, and (e) $70 \mathrm{~km} / \mathrm{h}$.

is $328.9 \mathrm{kN}$. It is evident that the frequency range increases with increasing truck speed and the dominant frequency with a range of 0 to $2 \mathrm{~Hz}$ at the speed of $5 \mathrm{~km} / \mathrm{h}$ becomes that with a range of $0 \sim 50 \mathrm{~Hz}$ at the speed of $70 \mathrm{~km} / \mathrm{h}$. Figure 12 shows the relationship between truck speed and dominant frequency of dynamic stress on the top of the base course. The first three dominant frequencies increase with the increase of truck speed. When the truck speed is $5 \mathrm{~km} / \mathrm{h}$, the first three dominant frequencies are $0.13 \mathrm{~Hz}\left(f_{1}\right), 0.33 \mathrm{~Hz}\left(f_{2}\right)$, and $0.47 \mathrm{~Hz}\left(f_{3}\right)$, respectively. When truck speed is $70 \mathrm{~km} / \mathrm{h}$, the first three dominant frequencies increase to $3.49 \mathrm{~Hz}\left(f_{1}\right)$, $10.48 \mathrm{~Hz}\left(f_{2}\right)$, and $13.97 \mathrm{~Hz}\left(f_{3}\right)$, respectively.
3.3. Effect of Depth. Figure 13 shows the dynamic pressure time history curves and spectrum curves at different depths when truck loading is $533.8 \mathrm{kN}$ and truck speed is $60 \mathrm{~km} / \mathrm{h}$. The dynamic pressure time history curves show that the influence of the front axle decreases gradually until disappearing and the compressive stress superposition phenomenon caused by rear double axles can be found with increasing depth. The maximum dynamic stress decreases from $84.6 \mathrm{kPa}$ to $10.9 \mathrm{kPa}$ as depth increases from $0.19 \mathrm{~m}$ to $3.12 \mathrm{~m}$. Besides, high frequency vibrations are absorbed by soil with increasing depth. Therefore, the dominant frequency is only $1 \mathrm{~Hz}$ when depth is $3.12 \mathrm{~m}$. 
TABLE 4: Maximum dynamic stresses under different truck loadings.

\begin{tabular}{lcccccccccc}
\hline \multirow{2}{*}{ Truck loading $(\mathrm{kN})$} & \multirow{2}{*}{ Depth $(\mathrm{m})$} & \multicolumn{9}{c}{ Truck speed $(\mathrm{km} / \mathrm{h})$} \\
& & 80 & 70 & 60 & 50 & 40 & 30 & 20 & 10 \\
\hline \multirow{3}{*}{533.8} & 0.19 & - & -81.9 & -84.6 & -82.7 & -86.1 & -83.7 & -80.7 & -94.6 & - \\
& 0.62 & - & -46.4 & -48 & -50.7 & -44.3 & -36.8 & -34.6 & -28.4 & - \\
& 1.42 & - & -45.1 & -41.4 & -42.5 & -39.4 & -39.4 & -33.9 & -31.7 & - \\
& 2.12 & - & -32.3 & -21.3 & -21 & -23.7 & -22.8 & -16.5 & -18.6 & - \\
& 3.12 & - & -14.6 & -10.9 & -11.3 & -13.9 & -16.9 & -12.9 & -12.9 & - \\
\hline
\end{tabular}

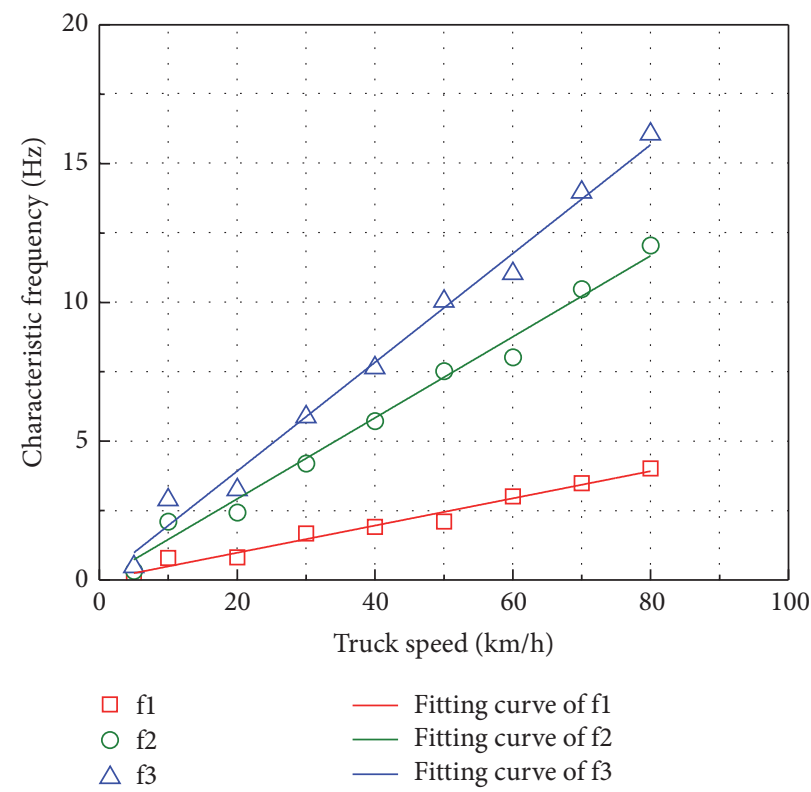

FIGURE 12: Relationship between truck speed and dominant frequency on the top of the base layer.

Table 4 shows the maximum dynamic stresses under different truck loadings. In general, dynamic pressure amplitude decreases dramatically with the increase of depth. This conclusion is consistent with the results of Park et al. [30], Xia et al. [31], and Feng et al. [32]. Table 4 also demonstrates that the greatest attenuation ratio of dynamic pressure is $87 \%$ as depth increases from $0.19 \mathrm{~m}$ to $3.12 \mathrm{~m}$. The dynamic pressure amplitudes are between $30 \mathrm{kPa}$ and $50 \mathrm{kPa}$ on the top of the up-embankment and are between $10 \mathrm{kPa}$ and $20 \mathrm{kPa}$ when the depth is $3.12 \mathrm{~m}$.

\section{Conclusions}

Field experiments were carried out with the purpose of investigating the dynamic compressive stress response of pavement-subgrade induced by moving heavy-duty trucks. The effects of truck loading, truck speed, and depth on amplitude and frequency of dynamic stress were analyzed. Based on measured results, the salient findings are summarized as follows.

(1) The dynamic pressure amplitude of each measuring point is strongly influenced by truck loading. The rear double axles load plays a significant role in the dynamic stress of pavement-subgrade and the maximum dynamic stress increases with increasing truck loading for a certain depth.
Furthermore, dominant frequencies are identical while the spectrum amplitude is different when the whole truck loading increases from $140 \mathrm{kN}$ to $533.8 \mathrm{kN}$.

(2) Truck speed has a certain effect on dynamic pressure. The dynamic pressure amplitudes of measuring points in the up-embankment and subembankment increase with the increase of truck speed. Moreover, the frequency range increases with increasing truck speed and the dominant frequency with a range of 0 to $2 \mathrm{~Hz}$ at the speed of $5 \mathrm{~km} / \mathrm{h}$ becomes that with a range of 0 to $50 \mathrm{~Hz}$ at the speed of $70 \mathrm{~km} / \mathrm{h}$.

(3) The dynamic pressure amplitudes are between $30 \mathrm{kPa}$ and $50 \mathrm{kPa}$ on the top of the up-embankment and are between $10 \mathrm{kPa}$ and $20 \mathrm{kPa}$ when depth is $3.12 \mathrm{~m}$. The dynamic pressure amplitude decreases dramatically with the increase of depth and the greatest attenuation ratio of dynamic pressure is $87 \%$. The dominant frequency is only $1 \mathrm{~Hz}$ when depth is $3.12 \mathrm{~m}$ because high frequency vibrations are absorbed by soil with increasing depth.

\section{Conflicts of Interest}

The authors declare that there are no conflicts of interest regarding the publication of this paper. 

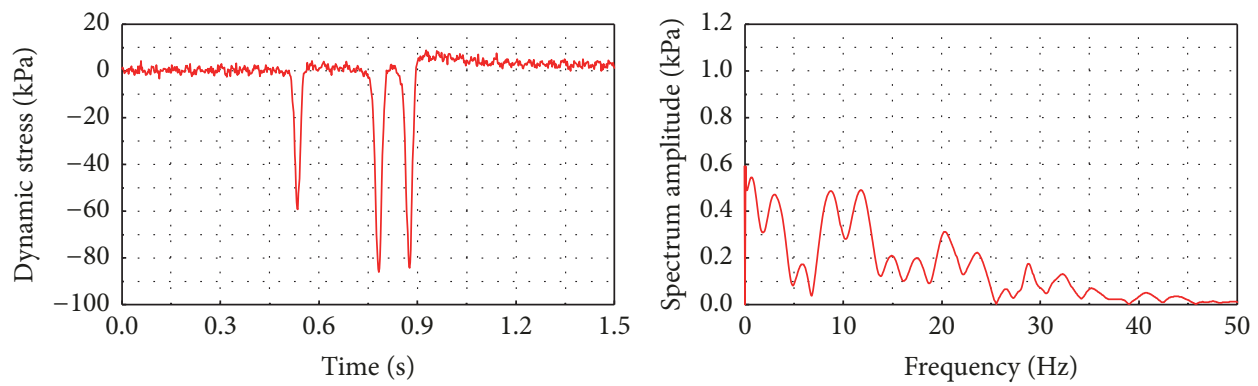

(a)
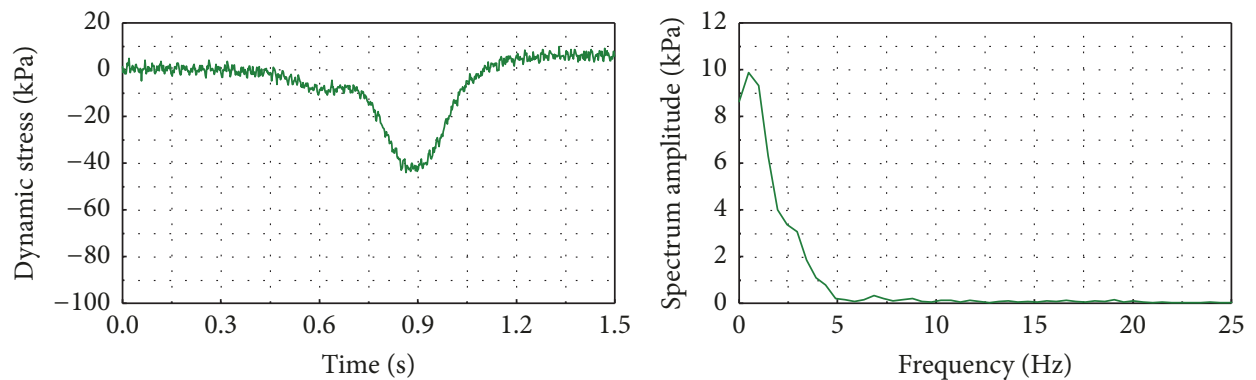

(b)
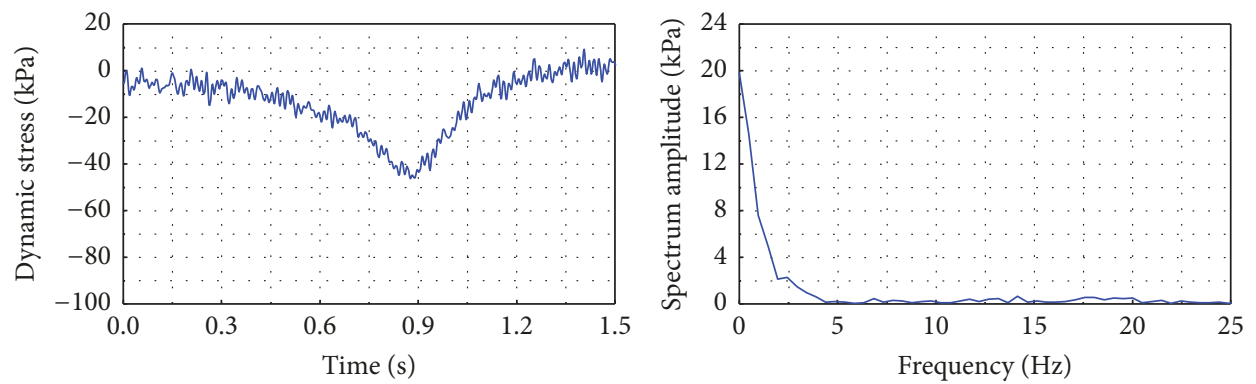

(c)
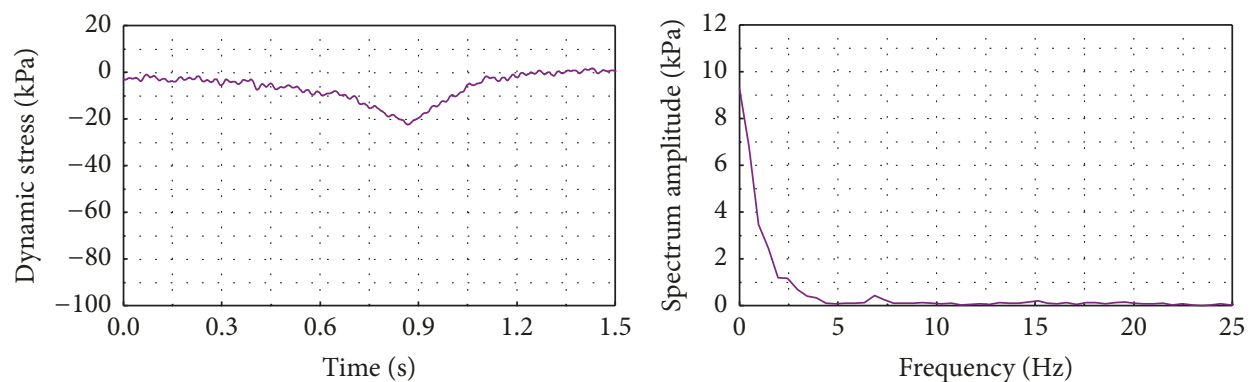

(d)
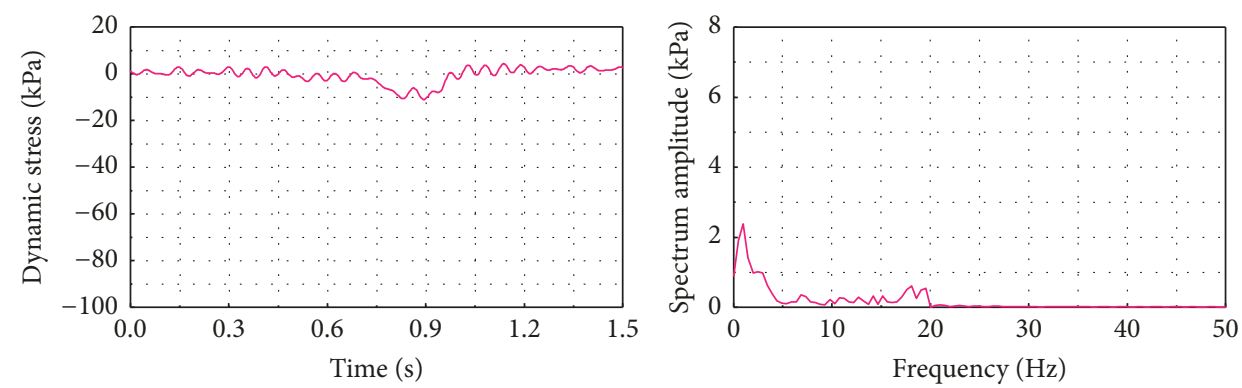

(e)

Figure 13: Dynamic pressure time history and spectrum curves when the depth is (a) $0.19 \mathrm{~m}$, (b) $0.62 \mathrm{~m}$, (c) $1.42 \mathrm{~m}$, (d) $2.12 \mathrm{~m}$, and (e) $3.12 \mathrm{~m}$. 


\section{Acknowledgments}

This research is supported by the National Natural Science Foundation of China (nos. 51578200 and 51408163), the Natural Science Foundation of Heilongjiang Province (no. ZD201218), China Postdoctoral Science Foundation Funded Project (no. 2012M520751), and the Fundamental Research Funds for Central Universities (no. HIT. NSRIF. 2014078).

\section{References}

[1] P. M. Lv, R. L. Tian, and X. Y. Liu, "Dynamic response solution in transient state of viscoelastic road under moving load and its Application," Journal of Engineering Mechanics, vol. 136, no. 2, Article ID 003002QEM, pp. 168-173, 2010.

[2] Y. Cai, Z. Cao, H. Sun, and C. Xu, "Dynamic response of pavements on poroelastic half-space soil medium to a moving traffic load," Computers \& Geosciences, vol. 36, no. 1-2, pp. 5260, 2009.

[3] R. A. Rahman, M. N. Tamin, and O. Kurdi, "Stress analysis of heavy duty truck chasis as a preliminary data for its fatigue life prediction using FEM," Computers and Geotechnics, vol. 26, pp. 76-85, 2008.

[4] T. Yoshimoto, "A Study of Rolling Resistance Measurement and Effect on Heavy-duty Fuel Consumption on Concrete Pavement," Concrete Journal, vol. 48, no. 4, pp. 11-17, 2010.

[5] B. Hultqvist and P. Jonsson, "Measurement of fuel consumption on asphalt and concrete pavements north of Uppsala," European Journal of Neuroscience, vol. 34, pp. 662-669, 2009.

[6] H. K. Salama, K. Chatti, and R. W. Lyles, "Effect of heavy multiple axle trucks on flexible pavement damage using inservice pavement performance data," Journal of Transportation Engineering, vol. 132, no. 10, pp. 763-770, 2006.

[7] R. Díaz, T. Echaveguren, and S. Vargas-Tejeda, "Heavy load trucks and its impact in life cycle of asphalt pavements," Revista de la Construccion, vol. 11, no. 1, pp. 101-118, 2012.

[8] Y. A. Tuffour, K. A. Tutu, and A. A. Obiriyeboah, "HotMix Asphalt Pavement Construction Practices in Ghana and Their Impact on Pavement Quality," International Journal of Construction Engineering and Management, vol. 3, pp. 109-116, 2014.

[9] C. Tirado, C. Carrasco, J. Mares, N. Gharaibeh, S. Nazarian, and J. Bendaña, "Process to estimate permit costs for movement of heavy trucks on flexible pavements," Transportation Research Record Journal of the Transportation Research Board, no. 2154, pp. 187-196, 2010.

[10] M. R. Mohd Hasan, J. E. Hiller, and Z. You, "Effects of mean annual temperature and mean annual precipitation on the performance of flexible pavement using ME design," International Journal of Pavement Engineering, vol. 17, no. 7, pp. 647-658, 2016.

[11] R. Tarefder and J. I. Rodriguez-Ruiz, "Local calibration of MEPDG for flexible pavements in New Mexico," Journal of Transportation Engineering, vol. 139, no. 10, pp. 981-991, 2013.

[12] A. Ongel and J. Harvey, "Prediction of lifetime for different asphalt concrete mixes," Road Materials and Pavement Design, vol. 13, no. 2, pp. 203-217, 2012.

[13] D. Singh, M. Zaman, and S. Commuri, "Inclusion of aggregate angularity, texture, and form in estimating dynamic modulus of asphalt mixes," Road Materials and Pavement Design, vol. 13, no. 2, pp. 327-344, 2012.

[14] M. I. Souliman, M. Mamlouk, and K. E. Kaloush, "Preliminary prediction of endurance limit for asphalt rubber mixtures,"
Canadian Journal of Civil Engineering, vol. 41, no. 11, pp. 964969, 2014.

[15] F. Xiao, P. E. Wenbin Zhao, and S. N. Amirkhanian, "Fatigue behavior of rubberized asphalt concrete mixtures containing warm asphalt additives," Construction and Building Materials, vol. 23, no. 10, pp. 3144-3151, 2009.

[16] D.-F. Lin, H.-L. Luo, H.-Y. Wang, and M.-J. Hung, "Successful application of CLSM on a weak pavement base/subgrade for heavy truck traffic," Journal of Performance of Constructed Facilities, vol. 21, no. 1, pp. 70-77, 2007.

[17] S. F. Brown, "Soil mechanics in pavement engineering," Géotechnique, vol. 46, no. 3, pp. 383-426, 1996.

[18] M. Hyodo, K. Yasuhara, and H. Murata, "Deformation Analysis of the Soft Clay Foundation of Low Embankment Road under Traffic Loading," in Proceeding of the 31st Symposium of Japanese Society of Soil Mechanics and Foundation Engineering, pp. 27-32, 1996.

[19] M. Hyodo and K. Yasuhara, "Analytical Procedure for Evaluation Por-Water Pressure and Deformation of Saturated Clay Ground Subjected to Traffic Loads," in Proceeding of the 6th Conference of Numerical Method in Geomechanics, pp. 653-658, 1998.

[20] A. Mateos, J. P. Ayuso, and B. C. Jáuregui, "Evaluation of structural response of cracked pavements at CEDEX transport research center test track," Journal of the Transportation Research Board, no. 2367, pp. 84-94, 2013.

[21] D. H. Timm, A. L. Priest, and T. V. McEwen, "Design and Instrumentation of the Structural Pavement Experiment at the NCAT Test Track," NCAT Report 04-01, 2001.

[22] S. Immanuel and D. H. Timm, "Measured and theoretical pressures in base and subgrade layers under dynamic truck loading," in Proceedings of the Airfield and Highway Pavement Specialty Conference, pp. 155-166, May 2006.

[23] J. M. Ling, W. Wang, and H. B. Wang, "On Residual Deformation of Saturated Clay Subgrade under Vehicle Load," Journal of Tongji University (Natural Science Edition), vol. 30, pp. 13151320, 2002.

[24] W. H. Zha, B. N. Hong, and Y. Xu, "Vibration Monitoring and Analysis of Low Embankment Freeway Pavement and Roadbed under Traffic Loadings," Highway Engineering, vol. 32, pp. 113117, 2007.

[25] W. Q. Wang, W. Z. Liu, and Y. Zhao, "Experimental Study on Structural Stress Response of Low Embankment under Traffic Load," Journal of Highway and Transportation Research and Development, vol. 2, pp. 39-41, 2007.

[26] X. Wang, J. S. Zhang, and G. Y. Yang, "Test on Dynamic pressure of Roadbed and Pavement under Heavy Loads," Journal of Vibration and Shock, vol. 26, pp. 169-173, 2007.

[27] J. Zhao, S. Liu, M. Shi, and H. Zhang, "Experimental study on dynamic response of low embankment under traffic load," Journal of Southeast University (Natural Science Edition), vol. 37, no. 5, pp. 921-925, 2007.

[28] F. Shi, J.-K. Liu, J.-H. Fang, Y.-H. Tian, and A.-H. Xu, "Subgrade dynamic stress test on highway in seasonal frozen soil area," China Journal of Highway and Transport, vol. 26, no. 5, pp. 1520, 2013.

[29] X. Cui, N. Zhang, J. Zhang, and Z. Gao, "In situ tests simulating traffic-load-induced settlement of alluvial silt subsoil," Soil Dynamics and Earthquake Engineering, vol. 58, pp. 10-20, 2014.

[30] D.-W. Park, A. T. Papagiannakis, and I. T. Kim, "Analysis of dynamic vehicle loads using vehicle pavement interaction 
model," Journal of Civil Engineering (JCE), vol. 18, no. 7, pp. 2085-2092, 2014.

[31] R.-X. Xia, J.-H. Li, J. He, and D.-F. Shi, "Effect analysis of vehicle system parameters on dynamic response of pavement," Mathematical Problems in Engineering, vol. 2015, Article ID 561478, 2015.

[32] Z. Feng, F. De-Cheng, L. Xian-Zhang, and L. Qiong-Lin, "Numerical simulation of dynamic response of subgrade under moving heavy truck in cold regions," Sciences in Cold and Arid Regions, vol. 5, no. 4, p. 468, 2013. 


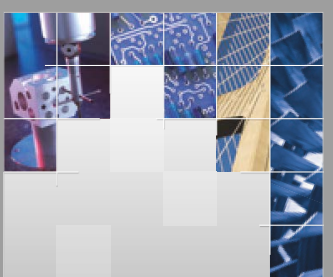

\section{Enfincering}
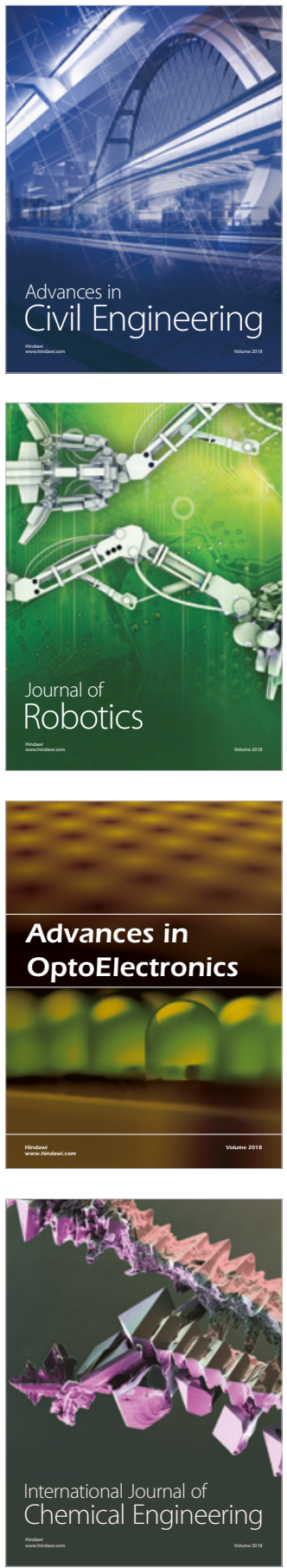

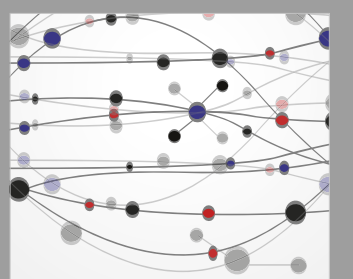

\section{Rotating \\ Machinery}

The Scientific World Journal

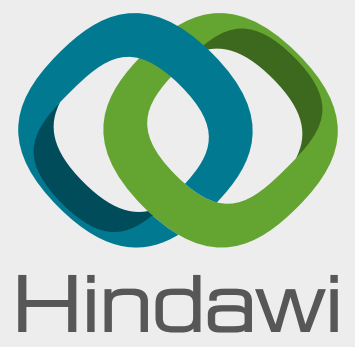

Submit your manuscripts at

www.hindawi.com
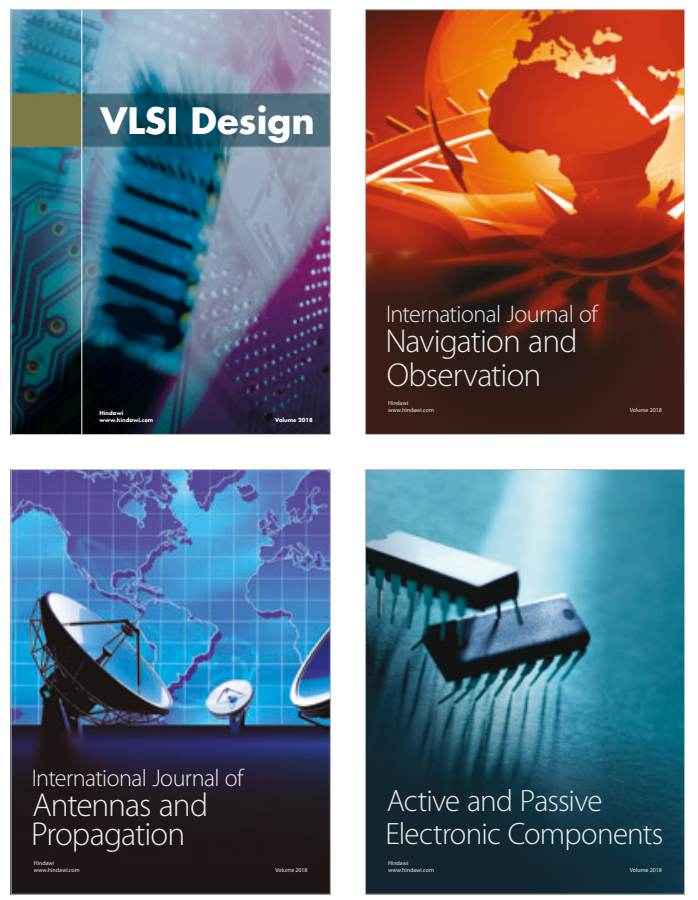
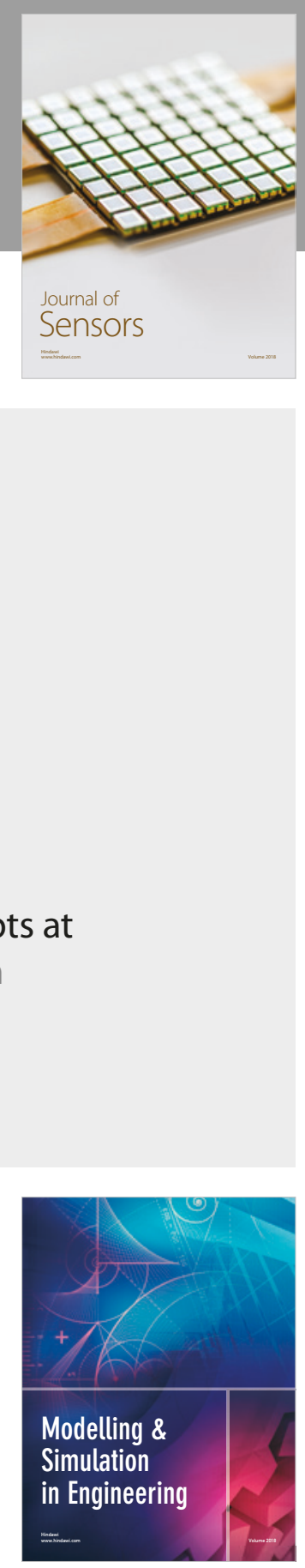

\section{Advances \\ Multimedia}
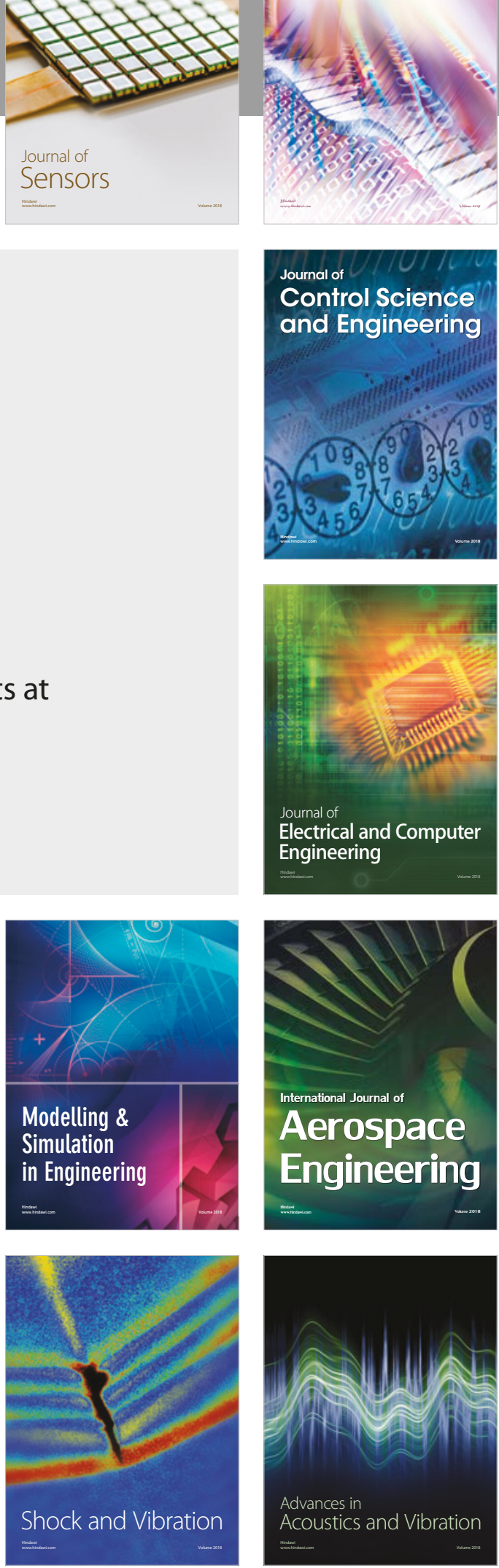